\title{
A DIFÍCIL TAREFA DE SER UM JUIZ "ATIVO E IMPARCIAL": UM OLHAR EMPÍRICO SOBRE OS PODERES INSTRUTÓRIOS DO JUIZ E O PRINCÍPIO DA IMPARCIALIDADE
}

\author{
Bárbara Gomes Lupetti Baptista ${ }^{1}$ \\ Daniel Navarro Puerari ${ }^{2}$
}

\section{RESUMO}

O presente trabalho se propõe, desde uma perspectiva empírica, a descrever, através da observação das práticas judiciárias e dos discursos dos magistrados fluminenses, se (e de que forma) o sistema processual civil brasileiro compatibiliza o postulado da imparcialidade judicial, corolário do acesso à justiça e do devido processo legal, com os poderes instrutórios do Juiz, tendência moderna resultante do ativismo judicial, que autoriza a produção de provas de ofício pelo magistrado. O texto busca refletir e problematizar como a imparcialidade se adéqua ao crescimento expressivo do "ativismo judicial", que divide a doutrina processual brasileira entre aqueles que consideram esse movimento extremamente danoso à imparcialidade e aqueles que aderem a essa tendência, assumindo-a como inevitável e até desejável para o alcance da verdade real no processo. A metodologia da pesquisa associa revisão bibliográfica, análise legislativa e incursão empírica, materializada em entrevistas formais e informais com advogados e magistrados e descrição de casos concretos observados durante trabalho de campo realizado no Tribunal de Justiça do Estado do Rio de Janeiro. Os resultados parciais da pesquisa explicitam a difícil tarefa e os dramas vivenciados por magistrados no exercício de sua atividade jurisdicional, demonstrando que, para eles, nem sempre é fácil situar-se entre o dever de ser imparcial e os ônus de ser um juiz ativo.

Palavras-chave: imparcialidade judicial; ativismo judicial; poderes instrutórios do juiz; pesquisa empírica.

\section{THE DIFFICULT TASK OF BEING AN "ACTIVE AND IMPARTIAL" JUDGE: AN EMPIRICAL LOOK AT THE JUDGE'S INSTRUCTIONAL POWERS AND THE PRINCIPLE OF IMPARTIALITY}

\begin{abstract}
From an empirical perspective, the present work describes, by observing the judicial practices and the speeches of the judges of Rio de Janeiro, whether (and in what form) the Brazilian civil procedural system harmonizes the postulate of judicial impartiality, a corollary of access to justice. justice and due process, with the Judge's instructive powers, a modern tendency resulting from judicial activism, which authorizes the production of exculpatory evidence by the magistrate. The text seeks to reflect and problematize how impartiality fits the expressive growth of "judicial activism", which divides Brazilian procedural doctrine among those who consider this movement extremely damaging to impartiality and those who adhere to this tendency, assuming it as inevitable and even desirable for reaching the real truth in the

\footnotetext{
${ }^{1}$ Professora do Programa de Pós-Graduação em Direito da Universidade Veiga de Almeida (PPGD-UVA). Professora da Faculdade de Direito da Universidade Federal Fluminense. Pesquisadora do INCT/InEAC.

${ }^{2}$ Professor dos Cursos de Graduação e Pós-Graduação da Universidade Estácio de Sá e Coordenador Adjunto do Curso de Direito - Unidade Ilha do Governador.
} 
process. The methodology of the research associates bibliographic review, legislative analysis and empirical incursion, materialized in formal and informal interviews with lawyers and magistrates and description of concrete cases observed during field work carried out at the Court of Justice of the State of Rio de Janeiro. The partial results of the research explain the difficult task and dramas experienced by magistrates in the exercise of their jurisdictional activity, demonstrating that it is not always easy for them to be between the duty of being impartial and the onus of being an active judge.

Key words: judicial impartiality; judicial activism; powers of the judge; empirical research

\section{Introdução: a explicitação do problema, dos objetivos e da metodologia da pesquisa}

O presente trabalho se propõe, desde uma perspectiva empírica, a descrever, através da observação das práticas judiciárias e dos discursos dos magistrados fluminenses, se (e de que forma) o sistema processual civil brasileiro compatibiliza o postulado da imparcialidade judicial, corolário do acesso à justiça e do devido processo legal, com os poderes instrutórios do Juiz, tendência moderna resultante do ativismo judicial, que autoriza a produção de provas de ofício pelo magistrado.

O texto busca refletir e problematizar como a imparcialidade se adéqua ao crescimento expressivo do "ativismo judicial", que divide a doutrina processual brasileira entre aqueles que consideram esse movimento extremamente danoso à imparcialidade e aqueles que aderem a essa tendência, assumindo-a como inevitável e até desejável para o alcance da verdade real no processo.

O objetivo principal do trabalho é, portanto, refletir sobre aquilo que nos parecer ser uma aparente incompatibilidade, ou até mesmo um paradoxo, do sistema processual civil brasileiro, que, apesar de ter nos inquietado, não costuma ser objeto de estranhamento e de problematização pelos atores do processo, e que diz respeito à essa difícil associação entre uma atividade jurisdicional que seja, ao mesmo tempo, imparcial e ativista.

Trata-se de pensar, portanto, sobre como compatibilizar a iniciativa probatória do juiz com o seu dever de imparcialidade.

Em síntese, a pergunta que ensejou o interesse de realizar uma incursão empírica sobre esse objeto decorreu da nossa perplexidade de imaginar como seria possível a um magistrado ser, ao mesmo tempo, ativista e imparcial?

A metodologia desta pesquisa associa revisão bibliográfica, análise legislativa e incursão empírica, materializada em entrevistas formais e informais com advogados e 
magistrados e descrição de casos concretos observados durante trabalho de campo realizado no Tribunal de Justiça do Estado do Rio de Janeiro.

Entre a análise de discursos doutrinários e práticas judiciárias, este artigo propõe, portanto, desde uma perspectiva empírica, realizada através de trabalho de campo no TJERJ, pensar sobre como o sistema processual e os magistrados, em seu fazer jurídico cotidiano, dão conta de equilibrar uma tendência cada vez mais moderna de se adotar uma postura ativista no processo com o seu dever de imparcialidade, que exige sua equidistância em relação às partes e um certo distanciamento com fins a evitar o comprometimento da atividade jurisdicional.

Privilegiamos a realização de pesquisa empírica neste trabalho, porque, de nossa parte, consideramos que a construção do conhecimento jurídico deve partir da realidade, a qual deve ser profundamente "devassada" e estudada, a partir da observação das práticas forense e da interlocução com os atores e sujeitos do processo.

A pesquisa empírica aqui realizada buscou o levantamento, o estudo e a análise dos dados obtidos por meio de trabalho de campo, in loco, e envolveu o exercício de um olhar apurado para a percepção da realidade que estudamos, contribuindo, a nosso ver, para a construção de um conhecimento científico criativo e original, pouco explorado, ainda, no campo do Direito.

De nossa parte, consideramos que o conhecimento doutrinário, que parte do estudo de certa literatura sobre algum tema específico, deve ser respeitado, posto que fundamental e complementar para qualquer pesquisa. Todavia, se apenas considerarmos este tipo de abordagem como suficiente para a produção do conhecimento, corremos o risco de nos tornarmos meros repetidores de doutrinas, pensadores de teses e "em tese".

Acreditamos, então, [e daí a justificativa pela eleição dessa metodologia de pesquisa, emprestada das ciências sociais, notadamente da antropologia], que os novos rumos para o estudo do direito precisam conceber uma visão crítica, reflexiva e construtiva da ciência jurídica, conforme já ressaltaram outros trabalhos de campo nessa área (KANT DE LIMA, 1997; LUPETTI BAPTISTA, 2013, p. 69).

A forma de construir o conhecimento, no campo jurídico, aprisiona a nossa subjetividade ao condicioná-la ao pensamento dos juristas consagrados, fazendo-nos partir sempre daquilo que eles já disseram e impedindo-nos de criar uma autoria própria. Nos dizeres de Kant de Lima (1997:37): “é um pouco como se as versões consagradas fossem a matéria-prima sobre a qual se edifica a atividade intelectual, que se limita a 'avançar' a partir daí, sem contestar seus próprios alicerces.”. Ora, ao elaborarmos nossos projetos, 
acabamos por inviabilizar novas formas de pensarmos o campo jurídico e, com isso, nos limitamos à sua reprodução.

[...] no campo do direito, trabalhamos, tradicionalmente, com textos escritos (livros de doutrina ou manuais dogmáticos), o que, em princípio, não seria suficiente para constituir de per si um obstáculo à produção do conhecimento científico dessa área, não fosse a ausência de reflexividade e a forma acrítica com que somos ensinados a olhar para o material bibliográfico com qual trabalhamos. No lugar de lermos os textos dogmáticos com a intenção de questioná-los e de problematizá-los, os lemos para acreditarmos neles e os reproduzirmos acriticamente. Com isso, quero destacar também que não precisamos associar, restritivamente, a pesquisa empírica ao trabalho de campo [...] como muito bem nos ensinaram, por exemplo, Castro Faria (2006), Dumont (2008) e Bourdieu (1968; 1974; 1983-a; 1983-b; 1989), a pesquisa empírica, de base antropológica, não exige, necessariamente, a realização de um trabalho de campo etnográfico. O diferencial está no olhar dirigido aos textos. Bourdieu, quando trata da constituição e da estrutura do campo científico e do campo intelectual, destaca que o que é importante metodologicamente é "pôr constantemente em dúvida" (1989:44), "impor uma visão crítica" (1989:49); se "autonomizar" (1968:108).

É justamente uma proposta metodológica inovadora e diferenciada como a que fora transcrita acima, que incorporamos nesta pesquisa, articulando distintos saberes e ferramentas de pesquisa, no caso, o método antropológico do trabalho de campo com a revisão bibliográfica produzida no campo jurídico, para compreendermos melhor o nosso objeto, que no caso, diz respeito ao estranhamento e a desconfiança (hipótese) de que o campo empírico tem dificuldades de compatibilizar o dever de imparcialidade dos magistrados com a tendência processual materializada na ideologia do ativismo judicial.

\section{O princípio da imparcialidade judicial}

A imparcialidade é um princípio do direito processual. Os artigos 144 ao 148 do Novo Código de Processo Civil (NCPC) tratam das causas de impedimento e de suspeição dos magistrados e traduzem situações concretas que, de per si, na concepção do Legislador, seriam comprometedoras de sua imparcialidade. Ademais, se trata de garantia processual, corolário do direito de acesso à justiça, e sustentáculo da ideia de jurisdição, sendo incorporada pela doutrina processual como "condição do legítimo exercício da função jurisdicional", constituindo-se como "essência da jurisdição" (GALDINO, 2011, p. 540).

As partes têm direito ao julgamento da lide por um juiz imparcial, que conduza o processo de forma desinteressada. 
Nas lições do Professor Leonardo Greco, “o direito de acesso à justiça é o direito a um julgamento por um juiz imparcial, ou seja, um juiz equidistante das partes e dos interesses a ele submetidos, que vai examinar a postulação no intuito exclusivo de proteger o interesse de quem tiver razão" (GRECO, 2005, p. 231).

Também é muito comum a doutrina associar o princípio da imparcialidade ao princípio da inércia da jurisdição, como bem salienta o autor Cassio Scarpinella Bueno: "essa necessária inércia jurisdicional tem a função de garantir a imparcialidade do Juízo, impondo ao interessado na prestação da tutela jurisdicional que requeira o que entender devido sempre ao Estado-juiz.” (BUENO, 2016, p, 90).

A imparcialidade é um pressuposto processual e os arts. 144 ao 148 do NCPC tratam, então, de vícios que, se verificados no caso concreto, comprometem a imparcialidade do juiz e, portanto, exigem o seu afastamento na condução do processo.

Os vícios que comprometem a imparcialidade do juiz estão divididos em vícios de impedimento (art. 144) e de suspeição (art. 145).

Os vícios de impedimento são tão graves, que, uma vez verificados, ensejam nulidade da sentença, arguível por via de ação rescisória (art. 966, inciso II, do NCPC), configurando questão de ordem pública e gerando presunção absoluta de parcialidade do juiz. Tratam-se de causas objetivamente verificáveis, explicitando critérios de aferição mais clara e racional.

Por sua vez, os vícios de suspeição têm conotação mais vaga e flexível, de ordem subjetiva, gerando presunção meramente relativa de parcialidade e sendo tratados de forma menos rígida no que se refere à nulidade, pois suscetíveis à preclusão. Ou seja, se as partes não apontarem os vícios de suspeição no prazo legal (15 dias) do art. 146, a sentença ou o ato praticado pelo juiz considerar-se-á válido, reputando-se tal vício como sanável.

Alexandre Câmara (2009, p. 137) destaca que “o impedimento é vício mais grave que a suspeição.”. Processualmente, isto significa dizer que os casos de impedimento geram nulidade absoluta ("presunção absoluta de parcialidade") e os de suspeição, relativa (“presunção relativa de parcialidade”) (GAJARDONI, 2009, p. 84).

O NCPC concentrou o estudo dos institutos em um só capítulo, dos arts. 144 ao 148, nos quais enumera os casos de impedimento e de suspeição e, ao mesmo tempo, cuida dos procedimentos relativos à sua arguição. 
Dessa forma, tem-se que um juiz imparcial "é um juiz equidistante das partes e dos interesses a ele submetidos, que vai examinar a postulação que lhe foi dirigida no intuito exclusivo de proteger o interesse de quem tiver razão, de acordo com a lei e as demais normas que disciplinem essa relação jurídica.”. (GRECO, 2005, p. 231)

CABRAL (2007, p. 341) menciona: “imparcialidade é alheação"; é indiferença à vitória de um ou de outro (ao contrário do que pensa BARBOSA MOREIRA, 2001, p. 29). Imparcialidade é, então, para CABRAL (2007, p. 342), um “mandado de distanciamento".

GALDINO (2011, p. 540) também ressalta a definição de imparcialidade como alheamento. O juiz é "um terceiro estranho" às partes. Ele atua em "em causa alheia" (2011, p. 553).

Um desembargador entrevistado foi taxativo quando consultado sobre a sua representação acerca do significado de "ser imparcial”: "É se manter distante das partes. Você é o juiz. Eles, as partes. Você tem um papel diferente e para exercê-lo, tem que estar igualmente distante das partes.".

Outro, comentou: "A imparcialidade é a alma da Justiça. Sem a imparcialidade não faz sentido nenhum a gente ter Justiça.”.

Desse modo, a imparcialidade judicial é um dever fundamental para se atingir um processo justo e, para tanto, o juiz precisa estar distante, igualmente, das partes do processo.

Esta sempre foi a representação do que seria o ônus da imparcialidade judicial.

No entanto, modernamente, a concepção de uma justiça equidistante foi dando lugar ao ideário do ativismo judicial, que colocaria o magistrado em um lugar menos passivo (logo, mais ativo e participativo), construindo-se uma nova percepção de imparcialidade.

Interessante analisarmos aqui, por exemplo, a nova formatação que assume a figura da deusa Themis, presente no imaginário dos atores que lidam com a justiça, como imagem de uma figura equidistante e que, justamente pela sua posição de deusa, se encontraria acima dos mortais por ela tutelados, com olhos vendados, e que, hoje, foi sendo reconfigurada, para uma imagem que vê por detrás da venda.

Justamente no que se refere à característica de "momentânea cegueira" causada pela venda em seus olhos (momentânea porque há uma venda em seus olhos, não se tratando, absolutamente, de uma deusa cega), podemos projetar para a sua figura a representação da imparcialidade, eis que ela supostamente não vê quem são as partes ou seus interesses particulares, pelo menos a priori, como observa Barbara Gomes Lupetti Baptista (2013, p. 
245), que fez um estudo dessa representação, desde a concepção clássica até a concepção contemporânea da figura da deusa, indicando, justamente, essa passagem do ideário de imparcialidade como equidistância para um novo contexto, que admitiria o ativismo judicial como algo que tiraria o juiz desse lugar mais omisso e distante, introduzindo num novo papel ativo:

Um procurador do munícipio ao qual eu perguntei expressamente sobre a questão da "cegueira da justiça", me disse: "Isso é passado, Hoje, a justiça enxerga muito bem. Os juízes estão buscando a melhor maneira de fazer Justiça, ainda que para isso precisem ir além do que diz a lei. É muito importante que o judiciário supra a sua inércia.". Pois bem. A imagem contemporânea da deusa Themis, que corresponde aos meus dados de campo, sugere uma deusa parcialmente vendada, com um dos olhos cobertos e o outro, bastante aberto, vendo tudo por debaixo da venda, de forma a ilustrar um sistema de justiça ambivalente, que permite que a deusa, de vez em quando, conforme o seu arbítrio, desvende um de seus olhos e enxergue parcialmente a realidade do caso concreto. A deusa que me parece representar, em imagem, o que a pesquisa revela em dados empíricos, é uma deusa que pode olhar por debaixo da venda, quando (e se) assim exigir o caso concreto. Ou seja, ela não está engessada e a sua venda não está colada em seus olhos. É certo que nem sempre ela retira a venda. Mas, se quiser, tem mecanismos que permitem enxergar o que a venda esconde.

Nessa mesma linha, caminhamos para tentar compreender como seria possível compatibilizar a necessária imparcialidade com a tendência de atribuir ao juiz poderes instrutórios? Ou seja, como o mesmo juiz pode ser, a um só tempo, imparcial e ativista?

\section{A tendência contemporânea do ativismo judicial e do uso de poderes instrutórios pelo magistrado: contrastes entre discursos doutrinários e observações empíricas}

Na condução do processo, o ativismo judicial é traduzido pela liberdade do juiz de se valer de poderes instrutórios na instrução processual, significa dizer, produzir provas de ofício.

Como cediço, mesmo no Direito Processual civil brasileiro, o juiz deve buscar a verdade real, isto é, procurar conhecer os fatos como ocorreram. Nessa medida, o juiz pode se valer dos poderes instrutórios concedidos pela legislação para dizer o Direito. Marinoni, Arenhart e Mitidiero (2015, p. 269-270) são expressos:

[...] O juiz tem o poder - de acordo com o sistema do Código de Processo Civil brasileiro -, quando os fatos não lhe parecerem esclarecidos, de 
determinar a prova de ofício, independentemente de requerimento da parte ou de quem quer que seja que participe do processo, ou ainda quando estes outros sujeitos já não têm mais a oportunidade processual para formular esse requerimento [...] se o processo existe para a tutela dos direitos, deve-se conceder ao magistrado amplos poderes probatórios para que possa cumprir sua tarefa.

$\mathrm{O}$ art. 370 do NCPC prevê que "caberá ao juiz, de ofício ou a requerimento da parte, determinar as provas necessárias ao julgamento do mérito", cabendo-lhe, ainda, "indeferir as diligências inúteis ou meramente protelatórias.”.

Especificamente sobre o indeferimento - pelo juiz - das diligências requeridas pelas partes (por inúteis ou protelatórias), caberia outra pesquisa, porque a forma casuística com que os magistrados deferem ou indeferem essas provas e os motivos que fundamentam essas decisões são os mais diversos e subjetivos possíveis e repercutem em distribuição desigual da justiça. No entanto, para os fins deste trabalho, considera-se o recorte sobre os poderes instrutórios do juiz e a sua postura ativista.

A questão que mobilizou o interesse por esta pesquisa estava vinculada a um questionamento básico: o uso da iniciativa probatória compromete a imparcialidade do juiz?

Diversos juristas pensam que inexistiria incompatibilidade entre os deveres de imparcialidade e de instrução probatória de ofício pelo Juiz.

Para SOUZA (2008, p. 99), a iniciativa probatória do juiz - tanto no processo civil quanto no penal - não compromete a imparcialidade judicial, porque essas "faculdades" do juiz visam “cumprir justa e eficazmente a função jurisdicional”. CAPPELLETTI (2001, p. 34) também reconhece a faculdade do juiz de usar poderes instrutórios nos limites da demanda. CAMPANELLI (2006, p. 63-64) é ainda mais incisiva, destacando pejorativamente o fato de que a "passividade e inércia judicial integram o modelo do processo civil dispositivo clássico, em que ao juiz é imposto comportamento passivo, sem outra função no curso do processo senão dirigi-lo", o que, segundo ela, representaria "um aspecto estritamente individualista do processo", onde a prestação jurisdicional é de interesse único das partes, característica que "não atende mais aos escopos do direito processual moderno, cuja tendência é da publicização".

Nesse sentido, a ideia de um juiz mais participativo na instrução justifica a ampliação de poderes do magistrado no processo civil, que não mais se contentaria com a verdade meramente formal. 
BEDAQUE (2009, p. 17) menciona que não é possível "admitir que a vontade dos litigantes seja um empecilho à atividade instrutória oficial, do juiz”. Para ele (2009, p. 71):

“[...] os sujeitos parciais do processo buscam apenas a vitória [...] produzindo provas favoráveis exclusivamente ao interesse próprio [...] compete ao juiz então manter o equilíbrio necessário ao bom funcionamento do mecanismo processual, agindo de forma imparcial e com o intuito de tornar possível a reprodução nos autos da realidade fática.".

E, ele próprio, BEDAQUE (2009), aponta o "temor da imparcialidade" como o principal obstáculo ao uso dos poderes instrutórios por parte de alguns magistrados. Em suas palavras: "criou-se a tradição do juiz passivo, espectador, temeroso de que qualquer iniciativa sua possa torná-lo parcial.”. (BEDAQUE, 2009, p. 114).

Diante dessa convicção, refletimos sobre a importância de uma análise empírica acerca das dificuldades de se compatibilizar essas duas leituras sobre o processo: de um lado, a exigência da imparcialidade e, de outro, a possibilidade de instrução processual de ofício. E, com isso, empreendemos o trabalho de campo que ensejou este texto.

\section{A difícil tarefa de compatibilizar a garantia da imparcialidade e os poderes} instrutórios do juiz: a compensação das desigualdades

O trabalho de campo que empreendemos nos permitiu perceber que o discurso de justificativa que os magistrados usam para se defender de sua suposta parcialidade, decorrente do uso exacerbado de poderes instrutórios no processo, se lastreava na ideia e na crença da "paridade de armas".

Sobre a paridade de armas, SILVA (2005, p. 33) destaca, em seu artigo intitulado, justamente, “A paridade de armas no processo civil”, que: “[ ...] o papel do juiz moderno no processo não é de mero espectador ou um 'mero convidado de pedra' [...] deve se preocupar em dar rumo ao processo de modo que todos devam dele participar com as mesmas oportunidades".

Segundo ele, "o processo não é um jogo onde vence o mais forte, o mais poderoso, o mais esperto, o processo é um instrumento de justiça.”. (SILVA, 2005, p. 33)

Nessa linha, o juiz seria o responsável por assegurar que o mais forte não vença simplesmente por ser mais forte. SOUZA (2008, p. 106) também explica esse mecanismo 
de defesa dos magistrados: "Há necessidade de se estabelecer um mecanismo que possa compensar essa desigualdade congênita [natural?] e que permita a todo participante da relação processual atuar em igualdade de armas.”.

Na concepção dogmática, portanto, o juiz inerte é o juiz que finge não ver a força do mais forte e, ao se omitir, permite que a força darwiniana do processo se estabeleça. Logo, entende-se que o juiz, ao ser inerte, acaba sendo também parcial.

SILVA (2005, p. 36) é expresso: "Não há dúvida de que a inércia judicial importará favorecimento da parte mais forte, violando, assim, o princípio da imparcialidade.”.

A paridade de armas, segundo nos disse um advogado, em entrevista de campo:

\begin{abstract}
"Significa colocar a parte fraca frente à parte forte. Equiparar fraco e forte. E quando eu digo fraco, eu tô falando da parte que é socialmente fraca. Então, quando você dá ao juiz poderes de iniciativa probatória, a ideia é que ele, em condições de paridade, impeça que o que é para ser igual fique desigual. O juiz não pode deixar que a ideia da igualdade jurídica vire uma desigualdade real. Então, para fingir que todos são iguais, ele trata como se fossem iguais, mas na realidade, eles são diferentes. Se eles são diferentes, ele tem que tratar diferente. Tem cultura inferior...é economicamente inferior...você não pode tratar como se não fosse. Isso é fazer injustiça. Por isso que a venda tem que ser tirada da justiça. O correto é que a deusa enxergue tudo e, ao manter os olhos abertos, veja as desigualdades e transforme essa desigualdades em igualdade. Ao ver as desigualdade, o juiz iguala. Se ele finge não ver, ele, na sua inércia, vai estar sendo parcial em favor do mais forte. Isso que é, para mim, a ideia da paridade de armas no processo civil.”.
\end{abstract}

E SILVA (2005, p. 39-40) ratifica esta visão:

\begin{abstract}
"Não há dúvidas de que o julgador deve ser imparcial e manter-se equidistante para que possa proferir uma sentença justa, mas isso não quer dizer que tenha de fechar os olhos diante do desequilíbrio das partes, pois, se assim o fizer, será parcial e a igualdade estará comprometida [...] o juiz não pode diante de um país como o nosso, onde são tão grandes as desigualdades e injustiças sociais [...] permanecer inerte na condução do processo.”.
\end{abstract}

Eis, portanto, a concepção de "parcialidade positiva", que sugere um novo paradigma da atividade jurisdicional, em que "acima de tudo", o juiz possa "reconhecer as diferenças sociais, culturais, econômicas, psicológicas, etc.” das partes e, com isso, uma 
“decisão équo e justa”. (SOUZA, 2008, p. 202). Em suas palavras (SOUZA, 2008, p. 211):

\begin{abstract}
"Reconhecer as desigualdades das partes, independentemente da posição que exercem na relação jurídica processual, é de rigor, não para igualálas concretamente, pois as diferenças sociais, culturais e econômicas sempre estarão presentes na realidade, mas, sim, para permitir a realização de atos concretos e eficazes que possam atenuar essa lamentável e indesejável circunstância da vida. A alternativa para esse lamentável quadro da natureza humana é realçar a parcialidade positiva do juiz, a fim de que, por meios legítimos conferidos pelo próprio ordenamento jurídico, e que não são poucos, possa promover-se o desenvolvimento da relação jurídica".
\end{abstract}

A noção de que a lei permite ao juiz ser parcialmente positivo advém tanto do art. 370 do NCPC, que, de fato, permite ao juiz ter iniciativa probatória, como acima mencionado, quanto da leitura que o campo faz sobre o significado do art. 139, inciso I, que diz que o juiz dirigirá de modo a assegurar às partes igualdade de tratamento. E o que ilumina a interpretação dessa norma? "A fórmula clássica: há que tratar igualmente ao igual e desigualmente ao desigual". (CAMPANELLI, 2006, p. 47; SOUZA, 2008, p. 62).

Eis a assertiva tradicional introduzida no campo jurídico por Rui Barbosa: "aquinhoar desigualmente aos desiguais, na medida em que se desigualam. Nesta desigualdade social, proporcionada à desigualdade natural, é que se acha a verdadeira lei da igualdade.”.(BARBOSA, 2003:39).

CAMPANELLI (2006, p. 45) também defende, literalmente, que "a concessão de tratamento absolutamente igual a todas as pessoas indistintamente gera desigualdades e desequilíbrios não pretendidos pelo Direito.”.

BEDAQUE (2009, p. 99) é igualmente taxativo ao manifestar que o reforço do poder instrutório do juiz é "um poderoso instrumento que o magistrado tem em suas mãos, que lhe possibilita corrigir as desigualdades econômicas presentes na relação processual.”.

Mas, e a imparcialidade? Esta foi a pergunta que nos mobilizou. E, de novo, a justificativa (WAMBIER, 1994, p. 142).

"O juiz, nesse contexto, seria parcial se assistisse inerte, como um expectador a um duelo, ao massacre de uma das partes, ou seja, se deixasse de interferir para tornar iguais partes que são desiguais. A interferência do juiz na fase probatória, vista sob este ângulo, não o torna parcial. Ao contrário, pois tem a função de impedir que uma das partes 
venha a vencer o processo, não porque tenha o direito, que asseverava ter, mas porque é economicamente mais favorecida que a outra. A circunstância de uma das partes ser hipossuficiente pode levar a que não consiga demonstrar e provar o direito que efetivamente tem. E o processo foi concebido para declarar, lato sensu, o direito que uma das partes tenha, e não para retirar direitos de quem os tem ou dá-los a quem não os tem.".

GRINOVER (1999, p. 71-79) também defende que os atos instrutórios do magistrado no processo judicial são positivos e não contrariam o princípio da imparcialidade. Segundo a autora, "longe de afetar sua imparcialidade, a iniciativa oficial assegura o verdadeiro equilíbrio e proporciona uma apuração mais completa dos fatos.".

Por tudo isso, percebemos que o juiz, de vez em quando, desloca a sua função para figurar como verdadeiro equilibrista no curso processual.

O problema que nos chamava a atenção e perdurava era pensar como, quando, por que motivos e em que circunstâncias o juiz deveria exercer o papel de equilibrista e quais os critérios. A empiria explicitou casuísmos e ambiguidades e este foi o ponto nevrálgico do trabalho de campo.

\section{O trabalho de campo: perplexidades e ambiguidades advindas das tentativas casuísticas de equilibrar a imparcialidade e os poderes instrutórios dos magistrados}

Devido à essa intensa produção dogmática que estimula o judiciário a usar poderes instrutórios e se valer de um conceito indeterminado de parcialidade positiva, verificamos, na empiria, que existem formas contraditórias de atuação do magistrado e de sua postura no curso do processo.

Alguns casos concretos e entrevistas serão transcritos aqui para ilustrar a imprevisibilidade do sistema e demonstrar o quanto a prestação jurisdicional se dá de forma aleatória e casuística.

Para tanto, começamos narrando o que um juiz entrevistado nos disse acerca de seu papel assistencialista no processo, passando, após, para a narrativa de casos específicos e de falas objetivas, que apontam a seletividade dos magistrados no trato dos seus poderes instrutórios (e em relação à sua imparcialidade):

Em tese, a imparcialidade significaria que nós não temos posições prévias e ideológicas. Então, eu não sei, mas talvez seja mesmo função do juiz fazer justiça social. Há muitos colegas que estigmatizam a mim e a outros magistrados que têm essa preocupação democrática, social, nos chamando de 
Robin Hood. Pra mim, dizer isso é já ter uma posição, que é a posição de manutenção do status quo da desigualdade. Eles dizem que nós temos uma ideologia, de proteção do pobre. Somos como Robin Hood. Mas eles também têm uma posição ideológica, que é a ideologia da conservação. Se é pra ter ideologia, eu tenho outra. Para tomar partido é para tomar pela parte mais fraca. Pra mim é assim que funciona. Senão mantém a estrutura perversa e desigual da sociedade e deixa tudo como está.

Outro magistrado também nos disse que, em nome da "igualdade, desigualo para igualar":

O assistencialismo acontece no Judiciário, não é incomum não. Essa questão da desigualdade e da igualdade...se o juiz perceber que a parte é muito mais fraca, ele vai tentar igualar as posições, porque a igualdade não é mais vista formalmente. Você tem desigualdades concretas e não só na magistratura, mas em qualquer área, você tem que diariamente lutar pra minimizar, pra acabar com essa desigualdade concreta. Isso é legítimo e dá pra fundamentar tranquilamente pela Constituição, a desigualdade material, então não vejo qualquer problema em o juiz atuar protetivamente. A constituição permite isso.

Mas nem sempre essa visão é uníssona ou bem recebida. Uma advogada usou a conhecida expressão popular "fazer caridade com o chapéu alheio" para criticar essa visão.

"O juiz faz muita caridade com o chapéu alheio. Aí, é muito fácil. 'Coitadinho, tá sofrendo, paga um dinheiro pra ele pelo amor de Deus'. O juiz tem pena de uma parte por qualquer motivo e acha que pode fazer caridade com o chapéu alheio. Eu defendo muito as empresas, na hora de defender a empresa chega lá o juiz na mesma hora acha que a empresa tem dinheiro: 'Doutora, faz um acordo, bota a mão no bolso'. E, no entanto, não sou eu que estou botando a mão no bolso; não é ele que está botando a mão no bolso dele; e a empresa não está aqui pra fazer caridade e sair distribuindo dinheiro. Na hora de fazer caridade com toda certeza a empresa tem responsabilidade social e faz caridade. Mas não com o direito. Aí o juiz, que tem o dever de julgar com imparcialidade, vai e se condói porque a parte é pobre. Isso não interessa. Se é pobre ou se não é pobre, ou se está precisando de ajuda ou não; interessa sim o fato dela ter direito a ganhar àquela indenização ou não.”.

E outra disse, citando outro ditado popular - "pimenta nos olhos dos outros é refresco":

De fato, a gente tem um determinado sentimento, uma tendência de 'vamos sempre simpatizar com o pobre, o coitadinho, o desamparado'. Eu também tenho esse sentimento, eu acho caridade um sentimento muito nobre, muito importante, mas eu acho também que se você quer vai lá e ajuda. Não é mandar o outro ajudar. Pimenta nos olhos dos outros é refresco, é mandar o outro ajudar, é fazer caridade enquanto você tá numa posição muito confortável. 
Uma juíza, na mesma linha exegética contrária ao assistencialismo que "desiguala para igualar", disse que faz caridade em asilo. No Judiciário não. Inclusive porque, segundo ela, a assistência social deve ser prestada pelo Executivo:

\begin{abstract}
Minha secretária me acha muito severa. Eu digo a ela: 'olha só, eu não presto assistência. Quando eu quero fazer bondade, eu vou lá no asilo e faço minha doação, no orfanato. Eu não estou aqui pra isso. Aqui é outro meu papel. Não é esse.'. No momento de julgar, você tem que estar isento disso para poder ponderar a situação de uma e de outra parte e dar uma solução justa para aquela situação sem permitir que as questões que estão fora do processo influenciem naquele julgamento. Eu acho inconcebível um juiz condenar um banco porque o consumidor que ajuizou a ação é pobre e é uma pessoa que não tem recursos e é um analfabeto. Eu tenho que dar razão a quem tem razão independente da situação social, econômica que envolva uma parte ou outra, sob pena de eu não ser justa. Para a imagem da justiça, eu acho muito ruim esses juízes assistencialistas. Não se pode confundir o papel do juiz. O juiz não está ali para fazer assistencialismo. Acho isso inconcebível. A gente tá aqui para fazer justiça. Para prestar justiça. E nem sempre a justiça está do lado do mais fraco. Até porque o judiciário não pode ficar suprindo uma deficiência que é do poder público em geral, de dar medicamentos, de dar condições dignas para as pessoas viverem. O judiciário não pode. Senão, vão achar, 'ah, vamos ali, porque ali, de qualquer maneira, alguma coisa a gente vai arranjar'. Isso é muito complicado.
\end{abstract}

No que se refere especificamente a como os magistrados usam seus poderes instrutórios, ou deixam de usá-los, para eventualmente compensar desigualdades processuais, eis um caso que me foi contado por um magistrado.

Não tem como ser imparcial. Por exemplo, os casos de seguro DPVAT, que é aquele seguro por acidente de trânsito que todo mundo tem direito. Vem aquelas pessoas, pobres, miseráveis, que às vezes foram atropeladas, ficaram com uma invalidez até permanente, com um advogado péssimo, que não pede a prova básica para o deferimento da indenização do seguro, que é a declaração do IML. O laudo do Instituto Médico Legal, né, que atesta o estado de invalidez permanente e qualifica a extensão do dano que a pessoa sofreu etc.. Aí, o advogado não pede. Se eu não tiver isso, o pedido é improcedente. O advogado não sabe. Você acha que eu vou julgar improcedente? Não mesmo. Determino de oficio que o IML mande o laudo. Agora, uma grande empresa, um banco, com toda a estrutura, deixa de fazer um pedido básico, de uma prova óbvia, como uma perícia de um cheque, por exemplo, ah...aí eu não determino de ofício não.

Eis outro caso narrado por um advogado, que estigmatiza o juiz do seu processo como sendo "assistencialista": 
Uma vez eu estava em uma audiência e era um caso de direito do consumidor. Eu era advogado da Ré, que é uma joalheria famosa. Aceitamos um cheque falsificado. Cheque roubado. A autora pedia danos morais e imputava à minha cliente a culpa por ter aceitado um cheque falsificado. $\mathrm{Na}$ verdade, a nossa defesa era de que a falsificação não era grosseira e, portanto, não haveria como percebermos a falsificação. Pedi a microfilmagem do cheque para provar justamente que a assinatura era idêntica e afastar a responsabilidade da joalheria. O Juiz indeferiu e disse na audiência, com raiva, nitidamente: 'Ah, por que quer a prova? Porque a JOALHERIA não quer pagar não, é? Uma joalheria desse porte não tem dinheiro para pagar a indenização? Indefiro a microfilmagem'. Ou seja, caso típico de que está com pena do consumidor, pensa que a joalheria é rica e então condena porque para o consumidor o dinheiro vai fazer diferença e para a joalheria não. E não deixa fazer a prova. Usa a instrução para decidir do jeito que quer.

Um magistrado também falou:

Eventualmente, tem advogados muito fracos mesmo, muito desidiosos e tal. Então, você tem duas saídas: ou você tem que suprir a deficiência da parte ficar pensando em todas as possibilidades que poderiam ter sido alegadas e pensando em tudo que poderia ter sido usado em favor da parte, e não foi, que é complicado, mas às vezes é uma saída. Ou então, desqualificar o advogado e nomear outro, oficiar a OAB etc. Você insta o sujeito a constituir outro advogado ou ele passa a ser defendido pela defensoria pública. São posturas do juiz que, na verdade, o que que ele tá fazendo? O juiz tá zelando por um processo justo. Não sei se isso é sair da situação de imparcialidade, porque, na verdade, ao fazer isso, estamos procurando calibrar a balança para as partes ficarem mais equilibradas. Mas, não sei, talvez seja ser parcial sim...aí, às vezes, você se substitui mesmo ao advogado mais fraco pra tentar ajudar a parte...né? Você atua. Essa coisa de produzir prova..o Professor Barbosa Moreira sempre diz que não tem problema e isso não é beneficiar nenhuma parte porque você não sabe o que a prova vai revelar, você não sabe quem a prova beneficia, a quem vai favorecer o resultado daquela prova, e pode ser a um ou ao outro. Mas e quando você pede a prova porque o advogado não pediu? A gente faz isso...acho que quando fazemos isso, já temos na cabeça que aquela prova é importante pra aquela pessoa desprotegida. Complicado isso mesmo...

Um juiz que eu entrevistei foi especialmente ilustrativo e didático para justificar o seu dever de "ajudar a parte":

Imagina se você fosse mãe e tivesse dois filhos. Um de dez anos e outro de três anos. Eles brigaram e você tem de resolver essa briga. Ver quem errou. O filho de dez anos te conta a história de um jeito. O de três, de outro. Cada um conta com o que pode. $O$ de três anos não se expressa muito bem, não sabe contar direito, não explica muito bem. Se de repente o de dez anos conta e você não entende, ele não te explica bem, você começa a desconfiar, 
porque ele está mais bem aparelhado. Se ele fala e você não entende é porque ele deve estar errado, querendo te enrolar etc.. O outro tem mais dificuldade, é natural, só tem três anos. Então, você faz perguntas de outro jeito pra ele. Você tenta ajudar de alguma forma. Não é pra beneficiar gratuitamente, com interesse. Mas pra saber mais a verdade. Do outro, você já espera que traga tudo. Quando ele não traz, gera até uma pretensão de que ele está pedindo um direito que não tem. Entendeu como é? $\mathrm{O}$ advogado fraco é como a criança de três anos...de repente ele não consegue, não sabe expressar o direito. Pela isonomia, você ajuda. Não é pra beneficiar. É para saber mais a verdade. Buscar melhor a verdade. Você não pode deixar ficar pessoal e querer beneficiar. Tem de ser na medida suficiente. Só o suficiente para aquela curiosidade a mais que você tem quando vê que a pessoa tem aquela dificuldade maior...é isso, uma criança de dez contra uma de três.

$\mathrm{Na}$ prática, o uso dos poderes instrutórios do juiz está bastante associado a essa questão da compensação das desigualdades. Foi muito comum que interlocutores dissessem que "ajudavam" a parte quando notavam, por exemplo, que ela estaria mal assistida pelo advogado e não requeria as provas necessárias.

Uma juíza com quem conversamos nos disse o seguinte:

Aqui nessa comarca [Niterói] o pessoal tem dinheiro. A maioria...não é um pessoal desassistido, desfavorecido. Então, aqui eu sou mais criteriosa nessa coisa de ajudar, de tentar facilitar. Mas eu vim de uma Cidade muito pobre, onde fiquei bastante tempo. Lá, não tinha jeito. Tinha que deixar passar algumas coisas, porque se eu fosse rigorosa com a lei, com os procedimentos, eu ia extinguir todos os processos. Lá eu produzia prova de ofício, determinava a vinda de documentos que a parte não juntava, tentava facilitar para o lado mais fraco...mandava esclarecer, em vez de extinguir direto...dava uma dica, sabe, do que eu estava querendo. Por exemplo: 'diga o autor se efetivamente desiste da produção da prova testemunhal', coisas assim sabe...para ajudar mesmo, senão não dava.

Verificamos em campo que o antídoto dos juízes entrevistados para justificar a sua atitude de usar poderes instrutórios para compensar desigualdades sem acreditar que isso feriria a sua imparcialidade era dizer que jamais o faziam para beneficiar pessoalmente algum das partes, mas sim para fazer justiça, buscar a verdade e adotar a ideologia da paridade de armas: "a gente determina prova de ofício para nós mesmos. Não é para beneficiar ninguém. Se for, aí sim é parcialidade.”. Dois magistrados nos disseram:

O juiz só pode usar os poderes instrutórios quando ele está em estado de perplexidade diante dos autos. Ou seja, se a determinação de produção de prova de oficio não é para retirá-lo de um estado de perplexidade, que permita a ele julgar, não pode usar. É invasivo e parcial. Agora, quando não 
dá para julgar nem procedente, nem improcedente e você não consegue julgar nem contra nem a favor, aí você não consegue saber o que aconteceu ali e como julgar aquilo, então, isso é estado de perplexidade que justifica ser mais ativo.

[...] se eu vejo que alguém deveria produzir uma prova e não tá produzindo, acho que não tem problema nenhum, aliás, o juiz deve fazer isso na verdade, no saneamento. É uma coisa que vários colegas não fazem e eu acho errado, que é dizer qual é o ponto da controvérsia. É um sinal de alerta para as partes. Acho que se pode dizer - pode não, tem que fazer - e dizer produzam provas sobre isso porque é isso daqui que eu estou vendo que é o ponto controvertido. A parte diz: não quero prova...aí, você dá uma decisão do tipo: 'digam as partes se efetivamente não desejam a produção de outras provas, importando o silêncio no julgamento no estado do processo'. Não posso fazer mais nada. Já dei uma dica. Agora, o justo é quando eu tô dizendo isso pra um e pro outro. Não pra beneficiar uma parte.

\section{Reflexões finais: a ausência de critérios e a consequente discricionariedade}

Os dados de campo explicitam que um sistema que determina aos juízes que sejam imparciais, mas ao mesmo tempo lhes autoriza desequilibrar a balança para igualar as partes, guarda uma ambiguidade estrutural e, nessa linha, parece ser incompatível com a imparcialidade a permissividade do uso de poderes instrutórios ao juiz.

Houve magistrados que disseram: "uso os poderes instrutórios para o meu convencimento.". Outros disseram: "uso quando minha consciência me manda julgar de um determinado modo, mas nos autos não tenho elementos". Outros: "quando sinto cheiro de fraude nos autos. Vou até o fim para descobrir".

Ou seja, a ausência de critérios sobre como, quando e por que usar os poderes instrutórios é a regra e o protocolo do campo. O critério é não ter critério padronizado. No discurso aparecem vozes mencionando que existem limites definidos, mas outras falas indicam que inexistem critérios. "Conduzir o processo é uma coisa. Fazer prova pela parte e favorecer a parte é outra. Isso é ser parcial. O juiz é juiz. Não advogada pra parte. Se quer advogar, larga a magistratura. Tira a toga.”.

O momento, a fase em que o juiz usa esses poderes instrutórios também diz muito sobre a sua intenção e a eventual quebra da imparcialidade. Por quê? Um desembargador explicou: 
"Por quê? Pelo seguinte. Quando o juiz vê que vai ter de julgar a favor de alguém - e talvez não esteja confortável com isso - aí ele tenta outra prova. Se ele determina a prova antes de começar a discussão, ainda passa...você pode pensar que a parte pode recorrer ao tribunal para discutir se o juiz, naquele caso concreto, podia ou não determinar a prova etc. Mas quando o juiz quer converter o julgamento em diligência para determinar a produção de uma prova que a parte não requereu, tendo outras provas nos autos, eu acho que existe invasão...acho que ele quer julgar de um jeito e os autos indicam outro...isso acontece. Infelizmente, mas acontece muito.".

Foram recorrentes falas no sentido de que "você sempre pode sugerir para a parte quando quer que ela produza uma prova que ainda não produziu. E se ela não faz a prova, você mesmo determina a produção.”.

Um desembargador nos contou como faz: “Ah, você pode dizer assim...'diga o autor se ratifica o pedido de julgamento antecipado da lide'. Para bom entendedor, meia palavra basta. Se você está pedindo ao sujeito para dizer se insiste no seu pedido de julgamento imediato é porque está querendo dizer a ele, 'olha, eu acho que precisa de prova ainda'.”.

Como não há critérios, finalizamos ilustrando o casuísmo:

A doutrina teoriza sobre os poderes instrutórios do juiz. Quer saber como funciona? Sinceramente, pode ter colegas que discordem de mim ou que não queiram assumir isso para você. Mas mesmo que seja inconscientemente, mesmo que seja sem querer favorecer diretamente uma das partes, o que acontece é o seguinte. A gente usa o nosso poder instrutório em duas situações: ou quando, na hora de julgar, queremos decidir de uma determinada forma, mas nos autos não temos elementos suficientes...aí mandamos fazer a prova para ver se temos elementos para julgar do jeito que achamos que é justo; ou quando uma das partes que nós achamos que tem o bom direito está mal assistida e não produziu a prova que precisa...aí também...vamos lá e mandamos fazer a prova que é importante para fundamentar o pedido. Senão, não usamos. Quando, por exemplo, a nossa consciência é pela procedência e já temos os elementos, para que vamos arrumar mais provas? Mas se queremos julgar procedente e não temos todos os elementos, aí mandamos fazer a prova. Você só inventa moda quando você precisa. Todo mundo vai dizer que não, mas é assim. Se você fizer uma pesquisa estatística, você vai ver: quando é que o juiz usa o seu poder instrutório? Na grande maioria, quando os autos já estavam conclusos para sentença e ele converte em diligência para fazer mais uma prova. Ou seja, ela ia julgar. Estava pronto... (juiz)

Como funciona isso? Aqui com o meu juiz, a gente faz o seguinte raciocínio: a pessoa faz uma ação que tem cinco pedidos ou argumentos diferentes. Se o juiz já está inclinado a julgar improcedente pelos outros argumentos e em um deles faltaria uma prova, que ele até pediria a produção de ofício, mas como está inclinado a julgar contra, não manda fazer a prova...a parte não traz a prova, o juiz está na linha da improcedência, aí não manda produzir. 
Mas se está inclinado pela procedência e a parte não traz a prova e ele não tem elementos. Em tese, teria de julgar improcedente. Mas se a inclinação é pela procedência, ele manda fazer a prova que talvez fundamente a procedência. Aqui a gente faz assim. Mas já trabalhei com juízes que nunca produziam. Já trabalhei com juízes que produziam sem critério, quando queriam, quando achavam importante. Tem de tudo. Cada um faz como acha melhor. (secretário de um juiz)

Os dados de campo mostram que os paradoxos e as ambiguidades que o nosso sistema jurídico produz, tais como, por um lado, as exigências legais da imparcialidade e, por outro lado, a atribuição de poderes instrutórios ao juiz e o seu dever de compensar desigualdades e prestar assistência à parte mais fraca no curso do processo, acabam por provocar a distribuição desigual da justiça, a partir de critérios casuísticos e imprevisíveis, comprometendo a segurança jurídica e impedindo a construção de um sistema isonômico e justo.

Além disso, os resultados parciais e empíricos da pesquisa explicitam a difícil tarefa e os dramas vivenciados por magistrados no exercício de sua atividade jurisdicional, demonstrando que, para eles, nem sempre é fácil situar-se entre o dever de ser imparcial e os ônus de ser um juiz ativo.

\section{Referências Bibliográficas}

BARBOSA MOREIRA, José Carlos. Temas de Direito Processual: sétima série. São Paulo: Saraiva, 2001, p. 19-30 e 251-261.

BARBOSA, Rui. Oração aos moços (texto integral). São Paulo: Martin Claret, 2003. . O neoprivatismo no processo civil. In: DIDIER JÚNIOR, Fredie. Teoria do

Processo: panorama doutrinário mundial. Volume 2. Salvador: Editora JusPODIVM, 2010.

BEDAQUE, José Roberto dos Santos. Poderes instrutórios do juiz. 4 ed. São Paulo: Editora Revista dos Tribunais, 2009.

CABRAL, Antonio. Imparcialidade e impartialidade. Por uma teoria sobre repartição e incompatibilidade de funções nos processos civil e penal. Revista de Processo - IBDP, São Paulo: Revista dos Tribunais, ano 32, n. 149, jul. 2007, p. 339-364.

CÂMARA, Alexandre Freitas. Lições de Direito Processual Civil. Vol. I. 19 ed. Rio de Janeiro: Lumen Juris, 2009. 
CAMPANELLI, Luciana Amicucci. Poderes instrutórios do juiz e a isonomia processual. São Paulo: Editora Juarez de Oliveira, 2006.

CAPPELLETTI, Mauro. O processo civil no direito comparado. Belo Horizonte: Líder, 2001.

GAJARDONI, Fernando da Fonseca. Recentes notas sobre o impedimento no direito processual civil brasileiro. Revista de Processo, São Paulo: Revista dos Tribunais, ano 34, n. 174, ago. 2009.

GALDINO, Flavio. Imparcialidade Judicial. In: ; LOBO TORRES, Ricardo; KATAOKA, Eduardo Takemi (Org.). Dicionário de Princípios Jurídicos. Rio de Janeiro: Elsevier, 2011.

GRECO, Leonardo. Estudos de Direito Processual. Campos dos Goytacazes: Editora Faculdade de Direito de Campos, 2005.

GRINOVER, Ada Pellegrini. A iniciativa instrutória do juiz no processo penal acusatório. RBCCrim, Revista Brasileira de Ciências Criminais, IBCCrim, São Paulo: Editora Revista dos Tribunais, v. 27, 1999.

LUPETTI BAPTISTA, Bárbara Gomes. Paradoxos e ambiguidades da imparcialidade judicial: entre “quereres" e “poderes”. Porto Alegre: Ed. Sergio Antonio Fabris, 2013.

MARINONI, Luiz Guilherme; ARENHART, Sérgio Gruz; MITIDIERO, Daniel. O Novo Processo Civil. Revista dos Tribunais: São Paulo, 2015.

SOUZA, Artur César de. A parcialidade positiva do juiz. São Paulo: Editora Revista dos Tribunais, 2008.

SILVA, Nelson Finotti. Paridade de armas no processo civil. Revista Jurídica. São Paulo: Notadez Informação Ltda. n. 327, jan. 2005, pp. 31-40.

SOUZA, Artur César de. A parcialidade positiva do juiz. São Paulo: Editora Revista dos Tribunais, 2008.

WAMBIER, Teresa Arruda Alvim. Reflexões sobre o ônus da prova. Revista de Processo. São Paulo: Revista dos Tribunais, ano 19, n. 76, out-dez. 1994, p. 141-145. 